\title{
Anthós
}

8-3-2017

\section{Unearthing Childhood: The Archeology of Children in North America}

Christine S A Vigeant

Portland State University

Follow this and additional works at: https://pdxscholar.library.pdx.edu/anthos

Part of the Archaeological Anthropology Commons Let us know how access to this document benefits you.

\section{Recommended Citation}

Vigeant, Christine S A (2017) "Unearthing Childhood: The Archeology of Children in North America," Anthós: Vol. 8: Iss. 1, Article 7.

https://doi.org/10.15760/anthos.2017.82

This open access Article is distributed under the terms of the Creative Commons Attribution-NonCommercialShareAlike 4.0 International License (CC BY-NC-SA 4.0). All documents in PDXScholar should meet accessibility standards. If we can make this document more accessible to you, contact our team. 


\section{Unearthing Childhood:}

\section{The Archeology of Children in North America}

\section{Christine Vigeant}

\section{Introduction}

The Archaeology of Childhood is a relatively recent focus of archaeological inquiry. An interest in prehistoric childhood comes on the heels of and as a necessary extension of feminist archaeology ${ }^{6}$ (Baxter 2008). Archaeological research in the past has largely ignored prehistoric children, or considered them only in the context of site formation processes or child burials (Schwartzman 2006). This neglect of prehistoric children was due to a belief that children were invisible in the archaeological record, because of their unpredictable behavior and their inactivity in the world of adults. They were thought to be passive participants rather than active influencers of their worlds (Baxter 2006).

The study of childhood in archaeology is relevant, because children are not invisible or irrelevant in the archaeological record as was previously believed. Children were not passive observers of prehistoric life, but actively shaped and influenced it. Children's needs and behaviors influenced adults' decision making and they

6 For a widely influential introduction to feminist archaeology see Margaret Conkey's and Janet Spector's 1984 paper Archaeology and the Study of Gender. Feminist archaeology critically examines the overlaying of a Western understanding of gender roles on prehistoric societies. It also challenges archaeology's undue focus on men in the archeological record (Conkey and Spector 1984). Increased awareness of the contributions of women in prehistoric societies subsequently opened the door for an increased focus on children. 
most likely contributed significantly to subsistence and influenced social organization (Kamp 2001).

The data on childhood is still fragmentary, but some of the investigations show great promise and are spurring innovative approaches to exploring the lives of children in the prehistoric past. A few archaeologists study children in their own right, rather than as tools to understand adults, and some of their work will be examined here (Schwartzman 2006). I will present the diverse work of several different researchers who contributed to the so far scant material on childhood in prehistoric North America. I will discuss Robert Park's work on miniatures of the Thule and Dorset cultures, Kathryn Kamp's study of juvenile pottery using fingerprint analysis, Patricia Smith's exploration into whether children were ceramic innovators, Greg Nelson and Felicia Madimenos' study of cranial deformation due to the use of cradleboards, and finally Mark Schurr's analysis of weaning behavior in three North American villages. The diversity of the studies presented here speaks to the fragmentary nature of the archaeology of childhood, but also of the multitude of ways in which children shaped prehistoric life and cultures.

\section{Theoretical and Methodological Challenges}

The study of the archaeology of childhood is inherently interdisciplinary. Data from multiple fields can be useful in helping to understand the roles and activities of children in the past. Attempting to isolate and analyze the activities of children is challenging and brings with it its own set of issues. The first difficulty lies in determining the definition of the term "child." The stages of 
childhood are cultural constructs that vary across time and space. One culture's child might be another culture's adult. There is also the question of how biological age and maturity correlate in different cultures. Children in hunter-gatherer societies may have had very different capabilities at different ages than children in our Western society (Schwartzman 2006).

Archaeologists, especially when studying children, often rely on ethnographic data to help interpret artifacts and structures they find. Bruce Trigger points out in Archaeology as Native History that it is dangerous to rely on this data, as it does not sufficiently account for change across time in native cultures. In the past it was common to assume that native cultures were static rather than dynamic and changing. Ethnographic data is also heavily colored by the mindset and culture of the people who recorded it (Trigger 1983). However, researcher Kelly Thomas challenges the idea that ethnographic data of contemporary children cannot be relied upon to help researchers understand the lives of prehistoric children. She studied the behavior of children in outdoor settings and argues that "play is a process by which children negotiate their space and position within the larger society of other children, adults, and natural surroundings. These elemental relationships are those that define and shape the child's world, and their expression through play creates a behavioral link to the archaeological record. Taking into account the historical and cultural contexts, ethnography can make explicit the processes and dimensions involved in the cultural construction of children and childhood" (Thomas 2006). 


\section{Data Presentation}

Huron Children as Stylistic Innovators

Cultures transmit their knowledge and skills to their children. Patricia Smith posed the question of whether Huron children of Ontario were innovators in the production of ceramics and actively helped to shape style. Smith used artifacts from seven sites dated to between $1280 \mathrm{AD}$ to $1649 \mathrm{AD}$ to conduct her inquiry. She argued that cruder pots were probably made by children, due to small size, and crudity in form and motif. Decorative features on ceramic vessels can be examined to determine culture change. Crude, smaller vessels made by children are generally not included in standard classification schemes. Smith found that juvenile pots exhibited somewhat different motifs from those of adult pots. She hypothesized that if children were indeed innovators in ceramic production, certain motifs should first appear on juvenile pots and later on adult pots. She chose to examine motif elements to focus on variation over time to test her hypothesis. She determined that three variations of motif elements were common on the pottery: oblique/vertical, horizontal, and geometric. Smith calculated the relative frequency with which these motif elements appeared on both juvenile and adult artifacts. She then divided the sites where the artifacts originated into three chronological periods to determine change over time and calculated the frequency of the motif elements for the different periods. 
Smith's work showed that adult and juvenile pots displayed different motif elements during the three time periods. She found that the geometric elements did not appear with enough frequency on the adult pots and did not include them in her final analysis. In order to prove her hypothesis that children were innovators, she determined that horizontal elements should first appear on juvenile vessels and later be found on adult pots. Her data revealed that the motifs did not follow the predicted pattern. Smith formulated a new hypothesis asking whether children were taught by adults in the application of motif elements. She focused on the oblique/vertical elements and determined that they should first appear on adult pots and later on juvenile pots. Her findings yielded the opposite results. She suggested that "children played an interesting role in innovation and transmission, since the decorations on juvenile pots are reminiscent of the past (their continued use of an element, horizontal, that was declining in popularity) but portend the future (their use of an increasingly popular element, oblique/vertical)" (Smith 2006). Smith also pointed out that children were quite creative, as was shown by the frequency of geometric motifs found on their vessels that were absent on adult vessels (Smith 2006).

Learning Pottery in the North American Southwest

Archaeologist Kathryn Kamp sought to determine whether less wellmade pottery was in fact created by children. She conducted experimental archaeology and asked 107 participants between the ages of 36 months to adult to recreate prehistoric ceramic figurines 86 
and vessels to gather data on the fingerprints imprinted on those vessels. She then compared this data to fingerprints on actual prehistoric artifacts of the Sinagua group from northern Arizona. Fingerprints do not change once the pattern is complete. The breadth of the ridges grows larger as the hand grows, however. Kamp found a strong correlation between ridge breadth and age. She calculated the ridge breadth of the fingerprints on clay figurines from the prehistoric artifacts and then compared them to the ridge breadth of the prints obtained from the replicas to determine the approximate age of the people who created the artifacts. She found that fingerprints that exhibited small ridge breadths were left by children and determined that some of the artifacts she examined were therefore made by children (Kamp 1999 and 2001).

\section{Miniature Archaeology of Childhood}

Inuit culture provides a rich ethnographic record and excellent preservation due to permafrost. It is therefore well-suited for the study of childhood archaeology (Park 2006). Here ethnographic information is crucial in helping researchers to understand the archaeological material. Inuit, and most likely their ancestors, don't think of children as completely new members of society or 'empty vessels', but rather as people with a pre-established identity (Park 1998). Robert Park argues that children used miniatures of commonly used adult tools for play and learning. Park provides data on almost 10,000 artifacts, including 369 miniatures that were excavated from Thule house ruins. 
He contrasts the frequency of miniatures with the frequency of fullsized tools of the same kind to find out what sorts of activities children participated in and whether they imitated the tasks of adults in their play.

Because of the large number of artifact types, Park organized the artifacts into concrete functional classes in order to be better able to compare them to ethnographic data. He chose the classifications “Archery”, "Harpooning”, "Fishing”, “Transportation”, “Other Men's Activities", "Women's and Household Activities", and "Other" (including dolls, which represented more than one quarter of all miniatures). Park found that in all categories, except "Other", there was a higher proportion of miniatures than full-sized artifacts. This was especially true for the "Archery" class, which accounted for $16.3 \%$ of miniatures, but only $6.8 \%$ of full-sized artifacts. Park argues that both boys and girls were given small bows and arrows, even though archery was a male activity. He explains an even higher discrepancy of $15 \%$ of miniatures versus $2 \%$ of full-sized items in the "Transportation" category with the fact that most artifacts were found in houses and that most full-sized sleds and transportation items likely were not stored inside. In other categories the proportions of miniatures and full-sized models were more comparable, suggesting that children were treated as small adults as the ethnographic data suggests, even in prehistoric times (Park 2006). 
To shed light on childhood subsistence patterns, Mark Schurr's study of weaning relied on skeletal remains to determine weaning age using stable nitrogen isotope ratios in bones. The isotope $15 \mathrm{~N}$ declines in bones as new foods replace breast milk in the diet. This data can be used to show whether the introduction of solid food was sudden or gradual. In this study, data from three sites in North America was examined to find out whether there was any relationship between weaning and fertility in the villages studied and how a change in subsistence influenced weaning behavior. Schurr gathered data from the prehistoric Middle Mississippian ceremonial center Angel site, inhabited between $1200 \mathrm{AD}$ and $1450 \mathrm{AD}$, the protohistoric MacPherson site in Ontario, inhabited by an Iroquoian tribe during the $16^{\text {th }}$ century, and historic Prospect Hill, a cemetery in New Market, Ontario, dated between 1824 AD and 1879 AD. The sites were all occupied by agriculturalists, are varied in space and time and provide a sufficiently large sample of remains to be useful in the analysis of weaning behavior and fertility in relation to subsistence.

None of the sites reached the maximum theoretical average limit of $15 \mathrm{~N}$ that can be achieved only after exclusive and prolonged breastfeeding. The isotope data reveals that weaning was initiated at an average age of 1.75 years at the Angel site, at 0.75 years at the MacPherson site, and at 1.25 years at the Prospect Hill site. Both, Angel and MacPherson data showed a slow, gradual weaning, despite the difference in ages at the onset of weaning. Prospect Hill individuals showed evidence of a rapid replacement of breast milk 
with other foods. Only individuals of the Angel site approached the theoretical maximum of $15 \mathrm{~N}$ and the evidence suggests that breast milk provided the main source of protein for children up to age two. Individuals at the MacPherson site only reached $60 \%$ of the maximum level, which suggests early weaning or supplementation, and individuals from Prospect Hill reached 90\%. The results did not show a correlation between agricultural dependency and weaning. Schurr argues that the early initiation of weaning at the MacPherson site was probably a reaction to stressors in the village's environment and indicates an attempt to increase fertility. Great demographic stress due to the arrival of Europeans may have contributed to this change in behavior (Schurr 1998).

\section{Cranial Deformation in the Puebloan Southwest}

Greg Nelson and Felicia Madimenos examined the flattening of skulls in human remains from the Puebloan southwest. Cranial deformation is commonly associated with the use of cradleboards during infancy. So far two different kinds of flattening, lambdoidal and occipital, have been recognized. Two remains of the Pueblo III Gallina site exhibited a third form of flattening, called obelionic. The authors surveyed and measured 146 crania dating to between 900 AD and $1400 \mathrm{AD}$ from six Puebloan sites to determine whether obelionic flattening was common in this area and whether a third category of flattening needed to be established. They found that of 146 examined crania, seven showed obelionic flattening. While they found some overlap in measurements between the three forms, they showed that obelionic flattening falls sufficiently outside the range of both other 
forms, and occurs in individuals of enough sites that it should be considered as a separate type. The types of flattening can point to changes in the manufacture and use of cradleboards over time (Nelson and Madimenos 2010).

\section{Data Evaluation}

The data highlighted here clearly shows that children had a significant impact on prehistoric life and that traces of their lives can be found in the archaeological record. Patricia Smith's study showed that Huron children were likely taught by their mothers and grandmothers how to make and decorate pottery, but were also allowed some artistic freedom. Her findings are evidence that children could indeed - at least to a certain degree, and in this particular culture - influence how products and tools were created. Kamp's and Park's research emphasized that children leave their own traces in the archaeological record and that these traces can be found and examined. Both studies also show that children participated in adult activities and were active learners to a large extent. Similarly, skeletal remains can provide a great deal of information about the lives of children. Methods of carrying children leave various, distinct traces on their crania, as Nelson and Madimenos documented. Childhood nutrition and weaning have an effect on fertility and can influence the demographics of a culture significantly. These subsistence patterns affect the health of a population as well. Decisions with regard to children are not made in a vacuum, but are heavily influenced by external factors.

The archaeological investigations presented here indicate 
some of the difficulties the archaeology of childhood presents. In the absence of specific markers, such as fingerprints, it can be extremely challenging to find conclusive evidence that artifacts were specifically made or used by children. Innovative approaches are needed and the development of a methodological and theoretical framework is necessary.

\section{Conclusion}

The archaeology of childhood is still in its infancy and leaves much to be explored. It is challenging to isolate children within the archaeological context and to study them in their own right, as Helen Schwartzman suggests (Schwartzman 2006), but it is certainly worthwhile. Ignoring the contributions and influences of prehistoric children is a detriment to archaeology as a whole. The data presented in this paper indicates that it is time to move away from the need to justify the validity of a focus on children in the archaeological record. The next necessary step is to incorporate the study of childhood into archaeology as a whole.

\section{References}

Baxter, J.E. 2008. The Archaeology of Childhood. Annual Review of Anthropology Vol. 37: 159- 175.

Baxter, J.E. 2006. Introduction: The Archaeology of Childhood in Context. Archaeological Papers of the American Anthropological Association Vol. 15: 1-9. 
Conkey, M. W., \& Spector, J. D. (1984). Archaeology and the study

of $\quad$ gender. Advances in archaeological method and theory Vol. 7: $1-38$.

Kamp, K.A., et.al. 1999. Discovering Childhood: Using Fingerprints to Find Children in the Archaeological Record. American Antiquity Vol. 64(2): 309-315.

Kamp, K.A. 2001. Prehistoric Children Working and Playing: A Southwestern Case Study in Learning Ceramics. Journal of Anthropological Research Vol. 57(4) Learning and Craft Production 427-450.

Kamp, K.A. 2001. Where Have All the Children Gone?: The Archaeology of Childhood. Journal of Archaeological Method and Theory Vol. 8(1): 1-34.

Nelson, G.C. and Madimenos, F.C. 2010. Obelionic Cranial Deformation in the Puebloan Southwest. American Journal of Physical Anthropology Vol. 143: 465-472.

Park, R.W. 2006. Growing Up North: Exploring the Archaeology of Childhood in the Thule and Dorset Cultures of Arctic Canada. Archaeological Papers of the American Anthropological Association Vol.15: 53-64.

Park, R.W. 1998. Size Counts: The Miniature Archaeology of Childhood in Inuit Societies. Antiquity Vol. 72.276: 269.

Schurr, M.R. 1998. Using Stable Nitrogen-Isotopes to Study Weaning Behavior in Past Populations. World Archaeology Vol. 30(2) Population and Demography 327-342. 
Schwartzman, H.B. 2006. Materializing Children: Challenges for the Archaeology of Childhood. Archaeological Papers of the American Anthropological Association Vol. 15: 123-131.

Smith, P.E. 2006. Children and Ceramic Innovation: A Study in the Archaeology of Children. Archaeological Papers of the American Anthropological Association Vol. 15: 65-76.

Thomas, K. 2006. The "Nature" of Childhood: Ethnography as a Tool in Approaching Children in Archaeology. Archaeological Papers of the American Anthropological Association Vol. 15: 41-50.

Trigger, B.G. 1983. American Archaeology as Native History: A Review Essay. The William and Mary Quarterly, Third Series, Vol. 40(3): 413-452. 